\title{
Future biogeochemical forcing in Eastern Siberia: cooling or warming?
}
A. Arneth ${ }^{1}$, S. Olin ${ }^{2}$, R. Makkonen ${ }^{3}$, P. Paasonen ${ }^{3}$, T. Holst ${ }^{2}$, M. Kajos ${ }^{3}$, M. Kulmala ${ }^{3}$, T. Maximov ${ }^{4}$, P. A. Miller ${ }^{2}$, and G. Schurgers ${ }^{2}$
${ }^{1}$ Karlsruhe Institute of Technology, Institute of Meteorology and Climate Research/Atmospheric Environmental Research, Garmisch Partenkirchen, Germany
${ }^{2}$ Department of Physical Geography and Ecosystem Science, Lund University, Sölvegatan 12, 22362 Lund, Sweden
${ }^{3}$ Department of Physics, University of Helsinki, P.O. Box 64, 00014 University of Helsinki, Finland
${ }^{4}$ Department of Plant Ecological Physiology and Biochemistry Lab., Institute for Biological Problems of Cryolithozone SB RAS, 41, Lenin ave, Yakutsk 677980, Russia

Received: 24 June 2014 - Accepted: 30 June 2014 - Published: 22 July 2014

Correspondence to: A. Arneth (almut.arneth@kit.edu)

Published by Copernicus Publications on behalf of the European Geosciences Union.

\section{Future \\ biogeochemical \\ forcing in Eastern \\ Siberia \\ A. Arneth et al.}

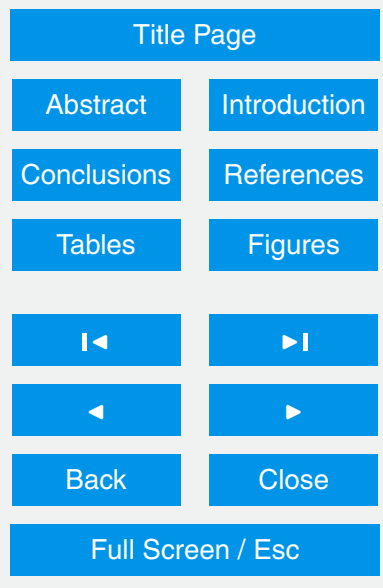

Printer-friendly Version

Interactive Discussion 


\section{Abstract}

Over-proportional warming in the northern high latitudes, and large carbon stocks in boreal and (sub)arctic ecosystems have raised concerns as to whether substantial positive climate feedbacks from biogeochemical process responses should be expected.

5 Such feedbacks occur if increasing temperatures lead to e.g., a net release of $\mathrm{CO}_{2}$ or $\mathrm{CH}_{4}$. However, temperature-enhanced emissions of biogenic volatile organic compounds (BVOC) have been shown to contribute to a cooling feedback via growth of secondary organic aerosol (SOA), and related aerosol forcings. Combining measurements in Eastern Siberia with model-based estimates of vegetation and permafrost 10 dynamics, BVOC emissions and aerosol growth, we show here that the additional climate forcing from changes in ecosystem $\mathrm{CO}_{2}$ balance and BVOC-SOA interactions nearly cancel on a regional scale. The interactions between emissions and vegetation dynamics that underlie individual forcing estimates are complex and highlight the importance of addressing ecosystem-climate feedbacks in consistent, process-based 15 model frameworks that account for a multitude of system processes.

\section{Introduction}

Warming effects on ecosystem carbon cycling in northern ecosystems (Serreze et al., 2000; Tarnocai et al., 2009), and the potential for large climate-feedbacks from losses of $\mathrm{CO}_{2}$ or $\mathrm{CH}_{4}$ from these carbon-dense systems have been widely discussed (Khvorostyanov et al., 2008; Schuur et al., 2009; Arneth et al., 2010). Other biogeochemical processes can lead to negative feedbacks, in particular through emissions of biogenic volatile organic compounds (BVOC) that act as precursors for secondary organic aerosol (SOA) formation and hence have a net cooling effect at clean-air locations (Arneth et al., 2010; Makkonen et al., 2012b; Paasonen et al., 2013). Condensation of monoterpenes (MT), a group of BVOC with large source strength from coniferous vegetation, on pre-existing particles increases the observed particle mass, as well
ACPD

$14,19149-19179,2014$

Future

biogeochemical

forcing in Eastern

Siberia

A. Arneth et al.

Title Page

Abstract

Introduction

Conclusions

References

Tables

Figures

14

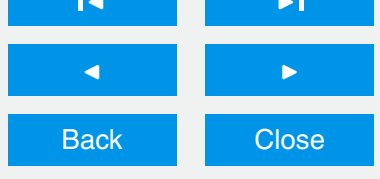

Full Screen / Esc

Printer-friendly Version

Interactive Discussion 
as the number of particles large enough to act as cloud condensation nuclei (CCN; equivalent to particles > ca. $100 \mathrm{~nm}$ ) at boreal forest sites (Tunved et al., 2006). For present-day conditions, Spracklen et al. (2008a) estimated a radiative cooling of -1.8 to $-6.7 \mathrm{~W} \mathrm{~m}^{-2}$ of boreal forest area, arising from the regional cloud albedo changes 5 associated with the BVOC-SOA interplay. How future changes in MT emissions affect SOA growth and climate is largely unknown.

The Russian boreal forest represents the largest continuous conifer region in the world. About one third of this forested area (ca. $730 \times 10^{6} \mathrm{ha}$ ) is dominated by larch (Shvidenko et al., 2007), in particular by the Larix gmelinii and L. cajanderii forests 10 growing east of the Yenisei river on permafrost soils. Despite its vast expanse, the first seasonal measurements of MT emissions from Eastern Siberian larch have only recently been published (Kajos et al., 2013). Leaf MT emission capacities are highly species-dependent, thus any model estimate of MT emissions from boreal larch forests that rely solely on generic BVOC emission parameterisations obtained from other conifer species will give inaccurate emission and SOA aerosol forcing estimates for this region (Spracklen et al., 2008a). We therefore provide here a first assessment of MT emission rates from the Eastern Siberian larch biome, combining measured emission capacities with a process-based dynamic vegetation model and quantitatively linking MT emissions and SOA formation. By estimating climate change effects on future vegetation composition, BVOC emissions and the concentration of particles of CCN size, we provide a comparative assessment of how the magnitude of the BVOC-SOA cooling compares with forcing from changes in the $\mathrm{CO}_{2}$ balance of Eastern Siberia.

\section{Methods}

\subsection{Site description, BVOC and aerosol measurements}

25 Leaf and canopy BVOC emissions fluxes, and aerosol particle size and number concentration were measured during the growing season 2009 at the research sta-

\section{ACPD}

14, 19149-19179, 2014

Future

biogeochemical

forcing in Eastern

Siberia

A. Arneth et al.

Title Page

Abstract

Introduction

Conclusions

Tables

References

\section{Figures}

14

$\Delta I$

4

Back

$>$

Close

Full Screen / Esc

Printer-friendly Version

Interactive Discussion 
tion Spasskaya Pad, located ca. $40 \mathrm{~km}$ to the northeast of Yakutsk $\left(62^{\circ} 15^{\prime} 18.4^{\prime \prime} \mathrm{N}\right.$, $129^{\circ} 37^{\prime} 07.9^{\prime \prime} \mathrm{E}$ ) and centred in the Eastern Siberian larch biome (Kobak et al., 1996; Tchebakova et al., 2006). In the northern direction, no major pollution sources exist within hundreds of $\mathrm{km}$, the nearest mining areas are concentrated to the south and west of Yakutsk. The predominant air flow to the site is either from southern (via Yakutsk) or northern locations. Forest fires contribute to aerosol load in summer.

An eddy covariance tower for measurements of forest-atmosphere exchange of $\mathrm{CO}_{2}$, water vapour and sensible heat was established at Spasskaya Pad in the late 1990s (Ohta et al., 2001; Dolman et al., 2004) in a L. cajanderii forest growing on permafrost soil with an understory vegetation consisting of ericaceous shrubs. The forest has an average age of ca. 185 years and canopy height is little less than $20 \mathrm{~m}$. Maximum one-sided larch leaf area index in summer is around two (Ohta et al., 2001). In 2009, leaf samples for BVOC analyses were taken, accessing the upper part of the canopy from a scaffolding tower located within few hundred metres of the eddy 15 flux tower (Kajos et al., 2013). Using a custom-made Teflon branch chamber, air filtered of $\mathrm{O}_{3}$ was sampled onto Tenax-TA/Carbopack-B cartridges with a flow rate of $220 \mathrm{~mL} \mathrm{~min}^{-1}$. A total of 5-12 samples were taken during the day, from two trees on south-facing branches approximately $2 \mathrm{~m}$ below the tree top. The cartridge samples were stored at $5{ }^{\circ} \mathrm{C}$ during the campaigns, transported afterwards to Helsinki and thermally desorbed and analysed using a thermal desorption instrument (Perkin-Elmer TurboMatrix 650, Waltham, USA) attached to a gas-chromatograph (Perkin-Elmer Clarus 600 , Waltham, USA). For details on chamber, adsorbents and laboratory measurements, see Haapanala et al. (2009); Ruuskanen et al. (2007); Hakola et al. (2006).

Aerosol particles were continuously monitored with a Scanning mobility particle sizer 25

(SMPS) located at the foot of the eddy covariance tower, connected to a Differential mobility analyzer (DMA; Hauke type: medium; custom built; for size segregation of aerosol particles) in front of a Condensation Particle Counter (CPC; 3010, TSI Inc. USA; for determining the number of the size segregated particles). The system was identical to the one described and evaluated in Svenningsson et al. (2008). Scans across the size

\section{ACPD}

$14,19149-19179,2014$

Future

biogeochemical

forcing in Eastern

Siberia

A. Arneth et al.

Title Page

Abstract

Introduction

Conclusions

Tables

References

Figures

14

$\rightarrow 1$

Back

Close

Printer-friendly Version

Interactive Discussion 
range of $10-500 \mathrm{~nm}$ are completed every $5 \mathrm{~min}$. The SMPS data were used to determine occasions of aerosol particle nucleation. The growth rates were calculated from log-normal modes fitted to the measured particle size distribution following Hussein et al. (2005). The time evolution of the diameters at which the fitted modes peaked was 5 inspected visually, and the growth rate was determined with linear least squares fitting to these peak diameters whenever a continuous increase in diameter was observed. In this analysis we calculated growth rates for particles from 25 to $160 \mathrm{~nm}$.

The source rate for condensing vapour $(Q)$ was determined by calculating the concentration of condensable vapour needed to produce the observed growth rate $\left(C_{\mathrm{GR}}\right.$, 10 Nieminen et al., 2010) and the condensation sink from the particle size distribution (CS, Kulmala et al., 2001). In steady state the sources and sinks for the condensing vapour are equal, and thus we determined the source rate as $Q=C_{\mathrm{GR}} \cdot \mathrm{CS}$.

\subsection{Modelling of dynamic vegetation processes, permafrost and BVOC emissions}

15 We applied the dynamic global vegetation model LPJ-GUESS (Sitch et al., 2003; Smith et al., 2001), including algorithms to compute canopy BVOC emission following $\mathrm{Ni}$ inemets et al. (1999), Arneth et al. (2007b), Schurgers et al. (2009a), and permafrost as adopted from Wania et al. (2009). LPJ-GUESS simulates global and regional dynamics and composition of vegetation in response to changes in climate and atmo20 spheric $\mathrm{CO}_{2}$ concentration. Physiological processes like photosynthesis, autotrophic and heterotrophic respiration are calculated explicitly, a set of carbon allocation rules determines plant growth. Plant establishment, growth, mortality, and decomposition, and their response to resource availability (light, water) modulate seasonal and successional population dynamics arising from a carbon allocation trade-off (Smith et al., 2001). Fire disturbance is included in the model (Thonicke et al., 2001). Similar to other DGVMs, a number of plant functional types (PFT) are specified to represent the larger global vegetation units (Sitch et al., 2003). Model results compare well with observations on LAI, permafrost distribution and vegetation response to warming (see main 19153

\section{ACPD}

14, 19149-19179, 2014

Future

biogeochemical

forcing in Eastern

Siberia

A. Arneth et al.

Title Page

Abstract

Introduction

Conclusions

References

Tables

Figures

14

\section{$\Delta$}

4

Back $\triangleright$

Close

Full Screen / Esc

Printer-friendly Version

Interactive Discussion 
text). Total present-day modelled soil $\mathrm{C}$ pools over the top $2 \mathrm{~m}$ in Eastern Siberia are $216 \mathrm{Gt} \mathrm{C}$, and $454 \mathrm{Gt} \mathrm{C}$ for circumpolar soils above $40^{\circ} \mathrm{N}$ (Table 1 ). A recent data-base estimated was 191,495 , and $1024 \mathrm{Pg} \mathrm{C}$ in the $0-30,0-100$ and $0-300 \mathrm{~cm}$ soil layer, of permafrost-affected soils, respectively (Tarnocai et al., 2009). These numbers indicate 5 that the values calculated with LPJ-GUESS are lower than observation-based ones, most likely underestimating $\mathrm{C}$-density in particular in the soil layers below few tenths of $\mathrm{cm}$.

BVOC emissions models, whether these are linked to DGVMs or to a prescribed vegetation map, all rely on using emission potentials $\left(E^{*}\right.$, leaf emissions at standard10 ised environmental conditions) or some derivatives as part of their algorithms. In LPJGUESS, production and emissions of leaf and canopy isoprene and monoterpenes are linked to their photosynthetic production, specifically the electron transport rate, and the requirements for energy and redox-equivalents to produce a unit of isoprene from triose-phosphates (Niinemets et al., 1999; Arneth et al., 2007b; Schurgers et al.,

2009a). A specified fraction of absorbed electrons used for isoprene (monoterpene) production $(\varepsilon)$ provides the link to PFT-specific $E^{*}$ (Arneth et al., 2007a); in case of monoterpenes emitted from storage an additional correction is applied to account for their light-dependent production (taking place over parts of the day) and temperaturedriven (taking place the entire day) emissions (Schurgers et al., 2009a).

Leaf BVOC emissions are stimulated in a future environment in response to warmer temperatures. Moreover, warmer temperatures and $\mathrm{CO}_{2}$-fertilisation of photosynthesis lead to enhanced vegetation productivity and leaf area, with additional positive effects on BVOC emissions. But higher $\mathrm{CO}_{2}$ concentrations have also been shown to inhibit leaf isoprene production. Even though the underlying metabolic mechanism is not yet fully understood, this effect has been observed in a number of studies (for an overview see Fig. 6 in Arneth et al., 2011). Due to limiting experimental evidence, whether or not a similar response occurs in monoterpene producing species is to date not confirmed, especially in species that emit from storage. The model is set-up to test this hypothesis (see Fig. A1). Multiple interacting processes can thus lead to enhanced

\section{ACPD}

14, 19149-19179, 2014

Future

biogeochemical

forcing in Eastern

Siberia

A. Arneth et al.

Title Page

Abstract

Introduction

Conclusions

References

Tables

Figures

14

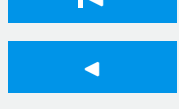

Back

$D$ I

$\triangleright$

Close

Full Screen / Esc

Printer-friendly Version

Interactive Discussion 
global monoterpene emissions in future, or - if the " $\mathrm{CO}_{2}$ inhibition" is included - yield emissions that are more or less similar to present-day or even slightly smaller (Arneth et al., 2007a; Schurgers et al., 2009a) (Table 1).

Monoterpene emissions can be emitted either directly following their synthesis, in 5 an "isoprene-like" fashion, or from storage pools, resulting in an emission pattern that is independent of light availability. The observed emissions of monoterpenes by larch possibly exhibit a hybrid between these two emission patterns (Kajos et al., 2013), as found also for other coniferous species (Schurgers et al., 2009a). In the model simulations performed here, half of the produced monoterpenes were stored, whereas 10 the other half was emitted directly.

LPJ-GUESS can be applied in forest-gap mode, in which forest successional dynamics and competition for water and light between individual age-cohorts are treated explicitly (Smith et al., 2001). The forest growth dynamics thus differentiate between early successional, short-lived species that invest into rapid growth rate vs. shade-tolerant trees with resource allocation towards longer-lived growth strategies. This allows to map the model's PFTs with tree-species when required information for model parameterisation is available. This feature provides a distinct advantage for applying the necessary BVOC emission capacities that is for applying the necessary BVOC emission capacities that are based on species (rather than functional-type) average values (Arneth et al., 2008; Schurgers et al., 2009b; Niinemets et al., 2010). Larch, in this model setup Larch, in this model setup, would be represented by the shade-intolerant boreal needle-leaf summergreen (BNS) PFT.

LPJ-GUESS was recently expanded with a permafrost module following Wania et al. (2009) and Miller and Smith (2012) in which a numerical solution of the heat diffusion equation was introduced. The soil column in LPJ-GUESS now consists of a snow layer of variable thickness, a litter layer of fixed thickness $(5 \mathrm{~cm})$, and a soil column of depth $2 \mathrm{~m}$ (with sublayers of thickness $0.1 \mathrm{~m}$ ) from which plants can extract non-frozen water above the wilting point. A "padding" column of depth $48 \mathrm{~m}$ (with thicker sublayers) is also present beneath these three layers to aid in the accurate simulation
ACPD

14, 19149-19179, 2014

Future

biogeochemical

forcing in Eastern

Siberia

A. Arneth et al.

Title Page

Abstract

Introduction

Conclusions

References

Tables

Figures

14

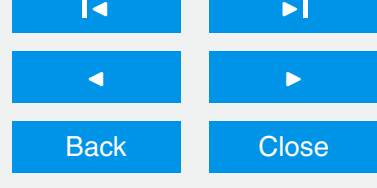

Full Screen / Esc

Printer-friendly Version

Interactive Discussion 
of temperatures in the overlying compartments (Wania et al., 2009). Soil temperatures throughout the soil column are calculated daily, and change in response to changing surface air temperature forcing and precipitation input, as well as the insulating effects of the snow layer and phase changes in the soil's water.

Here we run the model with $0.5^{\circ}$ spatial resolution, using climate and atmospheric $\mathrm{CO}_{2}$ as driving variables as described in (Smith et al., 2001). Values for the BNS "larch" PFT were adopted from the literature (Sitch et al., 2003; Miller and Smith, 2012; Hickler et al., 2012), but with the degree-day requirements on a five-degree basis (gdd5) to attain full leaf cover reduced from 200 to 100 (Moser et al., 2012). Minimum gdd5 10 to allow establishment was set to 350 to allow establishment of seedlings in very cold locations. Soil thermal conductivity was $2 \mathrm{~W} \mathrm{~m}^{-1} \mathrm{~K}^{-1}$. The modelled distribution of larch in LPJ-GUESS (Fig. 1) compares well with observation-based maps (Wagner, 1997). Simulations for the 21st century were based on ECHAM climate, using RCP 8.5 emissions (Riahi et al., 2007). The generated climate was adjusted to the CRU period be15 tween 1960 and 1990. $\mathrm{CO}_{2}$ inhibition of BVOC emissions were switched on and off. Totals across Siberia were calculated for a grid-box that ranged from 46 to $71^{\circ} \mathrm{N}$ and 76 to $164^{\circ} \mathrm{E}$. Simulated changes in total carbon uptake or losses were translated into radiative forcing following (IPCC, 2007), assuming a 50\% uptake in oceans in case of a net loss to the atmosphere (Sitch et al., 2007).

\subsection{Modelling aerosols and CCN}

To model the effect of BVOCs on CCN concentrations, we used the global aerosolclimate model ECHAM5.5-HAM2 (Zhang et al., 2012). ECHAM5.5-HAM2 includes black carbon, organic carbon, dust, sea salt and sulfate aerosols, and describes the aerosol size distribution with seven log-normal modes. The microphysics module M7

(Vignati et al., 2004) includes nucleation, coagulation and condensation. In this study, we use the ECHAM5.5-HAM2 version with activation-type nucleation and SOA formation from biogenic vapours as described in Makkonen et al. (2012b). In this approach, the monoterpene emissions from biosphere are first assumed to be mixed into the
ACPD

14, 19149-19179, 2014

Future

biogeochemical

forcing in Eastern

Siberia

A. Arneth et al.

Title Page

Abstract

Introduction

Conclusions

Tables

References

Figures

14

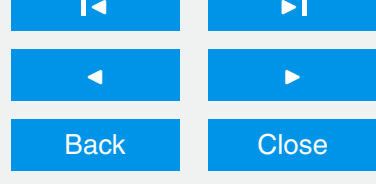

Full Screen / Esc

Printer-friendly Version

Interactive Discussion 
boundary layer, after which a fraction of $15 \%$ is assumed to form SOA. Half of the SOA is assumed to be of such low volatility that it can partition to particles already at nucleation size $(\sim 2 \mathrm{~nm})$, increasing the formation of $2-3 \mathrm{~nm}$ particles and hence the modelled total number concentration. However, most of the oxidized organic mass will 5 be distributed to larger aerosols, increasing the coagulation and condensation sink. The increase in sink will act to decrease formation of new particles (O'Donnell et al., 2011). Whether or not BVOCs can increase the availability of cloud condensation nuclei (CCN) depends on the availability of sub-CCN sized particles (O'Donnell et al., 2011). Anthropogenic primary emissions are introduced to the model as $60 \mathrm{~nm}$ parti10 cles, hence condensation of sulfuric acid and organic vapours is generally needed in order to grow these particles to CCN sizes. In Siberia, the modelled primary particle emissions are dominated by wildfires, which are assumed to inject large particles with $150 \mathrm{~nm}$ diameter.

ECHAM5.5-HAM2 was run with different BVOC emission scenarios in year 2000 and 152100 (see previous section). All simulations are initiated with a six months spin-up, followed by one year simulation for analysis. The model is nudged towards year 2000 meteorology, reducing the noise arising from differing meteorological fields. Anthropogenic aerosol and precursor emissions were taken from Dentener et al. (2006) for the year 2000 and from RCP-8.5 (Riahi et al., 2007) for the year 2100. The emissions of dust and sea salt are modeled interactively (Zhang et al., 2012). To study the effect of changing wildfire emissions on $\mathrm{CCN}$, we implemented one additional simulation pair with year 2000 and 2100 BVOC emissions with $E^{*}=1.9$, but both applying year 2000 wildfire and anthropogenic emissions. These simulations were also done with a slightly higher resolution of T63L31.

25 Estimates of radiative forcing due to changes in CCN followed Spracklen et al. (2008b). We calculate the change in cloud albedo $\left(\Delta R_{\mathrm{c}}\right)$ as

$\Delta R_{\mathrm{c}}=(1 / 3) R_{\mathrm{c}}\left(1-R_{\mathrm{c}}\right) \Delta \mathrm{CDNC} / \mathrm{CDNC}$
ACPD

14, 19149-19179, 2014

Future

biogeochemical

forcing in Eastern

Siberia

A. Arneth et al.

Title Page

Abstract

Introduction

Conclusions

Tables

References

Figures

14

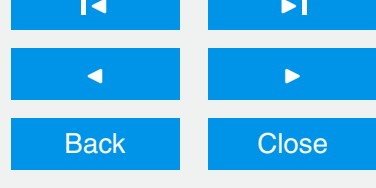

Full Screen / Esc

Printer-friendly Version

Interactive Discussion 
assuming that calculated $\mathrm{CCN}$ values correspond to changes in cloud droplet number concentrations (CDNC). Cloud albedo $R_{\mathrm{c}}$ is assumed to vary between 0.1 and 0.8 . From change in cloud albedo, we estimate change in short-wave forcing as

$$
\Delta F=-F_{0} A_{\mathrm{c}} T_{\mathrm{a}}^{2} \Delta R_{\mathrm{c}}
$$

5 where $F_{0}$ is top-of-atmosphere incoming solar radiation $\left(204 \mathrm{~W} \mathrm{~m}^{-2}\right), A_{c}$ is average cloud cover (assumed 0.65), $T_{\mathrm{a}}$ is fractional atmospheric transmission of short-wave radiation above cloud layer $(0.76)$.

\section{Results and discussion}

\subsection{Present-day BVOC emissions}

10 The dynamic global vegetation model LPJ-GUESS reproduces the present-day circumpolar permafrost distribution and, with the exception of the Kamchatka peninsula, simulates also the expanse of the larch-dominated forests in Eastern Siberia (Fig. 1, Miller and Smith, 2012; Tarnocai et al., 2009; Wagner, 1997). Maximum leaf area index (LAI) calculated by the model for the Spasskaya Pad forest, where the BVOC mea-

15 surements were obtained, was 2.0 (averaged over years 1981-2000; not shown), and is in good agreement with the measured values during that period (1.6, Takeshi et al., 2008). BVOC emissions models, whether linked to dynamic global vegetation models (DGVMs) or applying prescribed vegetation maps, require emission potentials $\left(E^{*}\right.$, leaf BVOC emissions at standardised environmental conditions) or some derivatives 20 as part of their algorithms. For the "larch" plant functional type in LPJ-GUESS (Schurgers et al., 2009a), $E^{*}=2.4 \mu \mathrm{g} \mathrm{C} \mathrm{m}^{-2}$ (leaf) $\mathrm{h}^{-1}$ was adopted in previous simulations from Guenther et al. (1995), a recommendation that at that time did not include observations from any larch species.

Kajos et al. (2013) measured for the first time MT $E^{*}$ from $L$. cajanderii. Their mea25 surements, taken over an entire growing season at Spasskaya Pad, suggested values 19158

14, 19149-19179, 2014

Future

biogeochemical

forcing in Eastern

Siberia

A. Arneth et al.

Title Page

Abstract

Introduction

Conclusions

Tables

References

Figures

14

$>$ I

4

Back

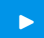

Close

Full Screen / Esc

Printer-friendly Version

Interactive Discussion 
of $E^{*}$ ranging from $1.9 \mu \mathrm{g} \mathrm{C} \mathrm{m}{ }^{-2}$ (leaf) $\mathrm{h}^{-1}$ at the lower end, to $9.6 \mu \mathrm{g} \mathrm{C} \mathrm{m}{ }^{-2}$ (leaf) $\mathrm{h}^{-1}$ at the upper. Applying a weighted measured-average $E^{*}$ of $6.2 \mu \mathrm{g} \mathrm{C} \mathrm{m}{ }^{-2}$ (leaf) $\mathrm{h}^{-1}$, increased simulated total present-day MT emissions across the Siberian larch biome from $0.11 \mathrm{Tg} \mathrm{Ca}^{-1}$ (as in Schurgers et al., 2009a) to $0.21 \mathrm{Tg} \mathrm{Ca}^{-1}$, or to $0.42 \mathrm{Tg} \mathrm{Ca}^{-1}$ 5 when the maximum $E^{*}$ was used (Table 1). The observed range in $E^{*}$, and the thus calculated range in total emissions across Siberia, might reflect variability in tree microclimate or genetic variability, or was induced by (undetected) mechanic or biotic stress during the time of measurements (Kajos et al., 2013). While our data are insufficient to make a finite suggestion of $L$. cajanderi $E^{*}$, the measurements provide evidence for potentially substantially higher MT emissions from Siberian larch than previous estimates.

\subsection{Present-day aerosols, and links to BVOC}

New particle formation events (Fig. 2a) were observed regularly. The calculated volumetric source rates of condensing vapours $(Q)$, the product of vapour concentration re-

quired for the observed particle growth rate and particle loss rate (Kulmala et al., 2005), increased exponentially with temperature (Fig. 2b). MT concentrations increased with temperature as well, with a slope relatively similar to that found for the $Q$ vs. $T$ relationship (Fig. 2c). Consequently, a positive relationship emerged between $Q$ and MT concentration (Fig. 2d), which supports previous field and laboratory evidence that MT and their oxidation products are a main precursor to the observed particle formation and growth.

Levels of radiation, which can be considered a surrogate for the concentration of the $\mathrm{OH}$ radical $(\mathrm{OH} \bullet)$, did not affect $Q$ (Fig. $2 \mathrm{~b}$ ), even though $\mathrm{OH} \bullet$ has been considered an important player for aerosol formation. This agrees with the findings by Ehn et al. (2014) that ozone instead of $\mathrm{OH}_{\bullet}$ is an important, if not the main, atmospheric agent oxidising organic vapours into a chemical form that condenses on particle surfaces. Thus,
ACPD

$14,19149-19179,2014$

Future

biogeochemical

forcing in Eastern

Siberia

A. Arneth et al.

Title Page

Abstract

Introduction

Conclusions

Tables

References

Figures

14

$\rightarrow 1$

Back

Close

Full Screen / Esc

Printer-friendly Version

Interactive Discussion 
additional factors to the concentrations of $\mathrm{SO}_{2}$ and $\mathrm{OH} \bullet$ are seemingly limiting aerosol production in non-polluted environments (Kulmala et al., 2005).

\subsection{Future carbon pools, vegetation distribution and BVOC emissions in Siberia}

In a warmer environment with higher atmospheric $\mathrm{CO}_{2}$ levels, the simulations indi5 cated drastically reduced area of permafrost in Siberia (Fig. 1). Total net primary productivity in the simulated domain increased from an annual average of $3.5 \mathrm{Pg} \mathrm{Ca}^{-1}$ to $5.9 \mathrm{Pg} \mathrm{Ca}^{-1}$ at the end of the 21 st century. An overall $\mathrm{C}$ loss of $100 \mathrm{Pg} \mathrm{C}$ (in the form of $\mathrm{CO}_{2}$ ) at the end of the 21st century was calculated from the shrinking Siberian areas of permafrost (Table 1). However, warming and higher levels of atmospheric $\mathrm{CO}_{2}$

10 led also to increasing LAI, and to larch dominated areas showing the expected northand north-eastwards shift (Fig. 1) compared to present-day climate (Miller and Smith, 2012). The carbon uptake in expanding vegetation into permafrost-free areas, combined with enhanced productivity across the simulation domain overcompensates for the losses from C-pools in permafrost areas (Table 1).

Future MT emissions were enhanced directly as a result of warmer leaves, and augmented by the future higher LAl of larch and evergreen conifers (Figs. 1d and A1; Table 1). Since the emissions scale with the emission factors applied, the proportional increase between present-day and future climate conditions is independent of the value of $E^{*}$. Whether or not leaf MT emissions are inhibited by increasing atmospheric $\mathrm{CO}_{2}$ 20 levels to similar degree to what was found for isoprene is difficult to asses from today's limited number of studies (e.g., Niinemets et al., 2010, and references therein). Similarities in the leaf metabolic pathways of isoprene and MT production suggest such an inhibition, but possibly this effect does not become apparent in plant species where produced MT are stored, unless the storage pools become measurably depleted by 25 the reduced production. By contrast, species emitting MT in an "isoprene-like" fashion immediately after production should more directly reflect $\mathrm{CO}_{2}$ inhibition. Evergreen conifers typically emit MT mostly from storage pools, whereas based on the leaf-level measurements, larch could follow a hybrid pattern between emission after production
ACPD

14, 19149-19179, 2014

Future

biogeochemical

forcing in Eastern

Siberia

A. Arneth et al.

Title Page

Abstract Introduction

Conclusions

References

Tables

Figures

14

$\Delta \mathbf{I}$

Back

Close

Full Screen / Esc

Printer-friendly Version

Interactive Discussion 
and from storage (Kajos et al., 2013). Without accounting for $\mathrm{CO}_{2}$ inhibition, MT emissions across the model domain more than doubled (Fig. 1; Table 1) by 2100, as a consequence of higher emissions per leaf area due to warmer temperatures, and of the larger emitting leaf area in response to higher photosynthesis.

Boreal vegetation has been shown to respond to the recent decades' warming and increasing atmospheric $\mathrm{CO}_{2}$ levels with a prolonged growing season and higher maximum LAI, similar to patterns in our simulations (Piao et al., 2006). The calculated enhanced biomass growth is in-line with experimental evidence of higher $C$ in plant biomass in warming plots at tundra field sites (Elmendorf et al., 2012; Sistla et al., 10 2013). In Siberian mountain regions, an upward movement of vegetation zones has been recorded already (Soja et al., 2007), while the analysis of evergreen coniferous undergrowth abundance and age shows spread of evergreen species, especially Pinus siberia, into Siberian larch forest (Kharuk et al., 2007). These observations thus support the modelled shift in vegetation zones, and change in vegetation type composition 15 and productivity.

Estimates of carbon losses from northern wetland and permafrost soils in response to 21st century warming range from a few tens to a few hundreds $\mathrm{Pg} \mathrm{C}$, depending on whether processes linked to microbial heat production, thermokarst formation and surface hydrology, dynamic vegetation, $\mathrm{C}-\mathrm{N}$ interactions, or fire are considered (Khvorostyanov et al., 2008; Schuur et al., 2009; Arneth et al., 2010; Koven et al., 2011; Schneider von Deimling et al., 2012). A modelled range of $0.07-0.23 \mathrm{~W} \mathrm{~m}^{-2}$ forcing associated with a 33-114 $\mathrm{Pg} \mathrm{CO}_{2}-\mathrm{C}$ loss from permafrost regions was found for a simulation study that was based on the RCP 8.5 climate and $\mathrm{CO}_{2}$ scenarios, but excluding full treatment of vegetation dynamics (Schneider von Deimling et al., 2012).
In our simulation, the $\mathrm{CO}_{2}-\mathrm{C}$ loss from the decreasing Siberian permafrost region would be equivalent to a 0.13 additional $\mathrm{W} \mathrm{m}^{-2}$ forcing in 2100 (see Sect. 2). But this carbon loss was offset when taking into account vegetation dynamics and processes across the entire Siberian study-domain (Table 1), including a shift in PFT composition, and enhanced productivity especially in the southern regions, such that the overall carbon
ACPD

$14,19149-19179,2014$

Future

biogeochemical

forcing in Eastern

Siberia

A. Arneth et al.

Title Page

Abstract

Introduction

Conclusions

References

Tables

Figures

14

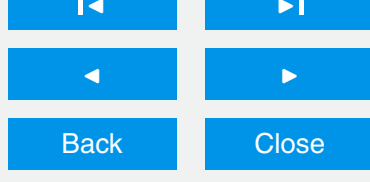

Full Screen / Esc

Printer-friendly Version

Interactive Discussion 
uptake including enhanced net primary productivity and expanding woody vegetation resulted in a small negative $\left(-0.09 \mathrm{~W} \mathrm{~m}^{-2}\right)$ forcing.

These overall small effects from the net changes in $\mathrm{CO}_{2}$ could become of secondary importance compared with how increased MT emissions affect aerosol forma5 tion, if an estimated growing-season indirect radiative cloud albedo forcing feedback of $-0.5 \mathrm{~W} \mathrm{~m}^{-2} \mathrm{~K}^{-1}$ for the Siberian larch region (Paasonen et al., 2013) applies to an increase of the region's growing season temperatures of ca. $5.5 \mathrm{~K}$ simulated at the end of the 21 st century in our study. The observation-based indirect feedback factors exceeded direct ones by roughly an order of magnitude (Paasonen et al., 2013), but such 10 a simple extrapolation does not account for important non-linearities in the system. Present-day CCN concentration over Siberia was estimated to vary from extremely low values of less than $50 \mathrm{~cm}^{-3}$ around $60^{\circ} \mathrm{N}$ to $100-200 \mathrm{~cm}^{-3}$ in the north-east (Fig. 3). Over the larch-dominated are (Fig. 1) the sensitivity of CCN to $E^{*}$ was $5-10 \%$. In the future, a scenario of decreasing anthropogenic emissions led to a strong decrease in calculated atmospheric $\mathrm{SO}_{2}$ concentrations and also of particle nucleation. What is more, SOA formation only partly enhances the survival of small particles by providing additional growth (Makkonen et al., 2012a), but partly also suppresses it by increasing the coagulation sink for small particles (Fig. 4, lower panel, O'Donnell et al., 2011). Figure 4 demonstrates that relatively higher emission of BVOC (e.g., by comparing the high and low value of measured $E^{*}$ ) under ambient and future conditions leads to increased aerosol growth rates (GR), with over $10 \%$ increase in GR in large part of the Siberian domain. However, increased aerosol mass due to increased SOA formation led to an increase in condensation sink and eventually to decreased particle formation rates (Fig. 4). This decrease can be seen also in the total particle concentration over large parts of Eastern Siberia (Fig. 4, top panel). Even with accelerated small particle growth by organic vapours, the increasing sink with higher $E^{*}$ led to decreased new particle formation rates (Fig. 4). These interactions could lessen the relative importance of the cloud albedo forcing feedback. In addition, the cooling by future BVOC emissions

\section{ACPD}

14, 19149-19179, 2014

Future

biogeochemical

forcing in Eastern

Siberia

A. Arneth et al.

Title Page

Abstract

Introduction

Conclusions

References

Tables

Figures

14

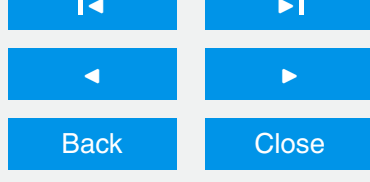

Full Screen / Esc

Printer-friendly Version

Interactive Discussion 
may also be altered through changes in aerosol background (e.g., fire), which strongly influences the indirect aerosol effect of SOA (Fig. 5).

The increase in $\mathrm{CCN}$ concentration due to increasing future BVOC emission (Figs. 4 top right panel and Fig. 3) is around $5-10 \mathrm{~cm}^{-3}$ north of $60^{\circ} \mathrm{N}$. Figure 5 shows the size5 resolved effect of BVOC increase on SOA formation separately for areas of high and low wildfire emission (separated by an emission limit of $10^{-11} \mathrm{~kg} \mathrm{~m}^{-2} \mathrm{~s}^{-1}$ ). In large parts of Siberia, the simulated BVOC oxidation products condense on CCN-sized aerosols already present from wildfires. In the applied future scenarios, Siberian wildfire intensity was assumed to increase (Makkonen et al., 2012a). In areas of low wildfire activity, 10 the increase in SOA formation was proportionally high $(60 \%)$ in nucleation mode $\left(d_{\mathrm{p}}<\right.$ $10 \mathrm{~nm}$ ), and the relative increases in SOA formation in Aitken, accumulation and coarse modes were $50 \%, 31 \%$ and $40 \%$, respectively. However, the distribution of BVOC oxidation products was rather different in areas of high wildfire activity. SOA formation in coarse mode was more than doubled, while SOA in nucleation mode decreased by $1530 \%$. It is clear that the effect of increased BVOC emission on particle population has distinct effects depending on existing background aerosol distribution. Averaged over Siberian areas of low wildfire activity, the median (mean) increase of CCN $(0.2 \%)$ was calculated to be $1 \%(7 \%)$ due to BVOC emissions changes from year 2000 to year 2100 , while areas of high wildfire emission lead to median (mean) increase of $0.3 \%$ $20 \quad(0.5 \%)$.

Even though the Siberian MT emissions more than double until 2100 (Table 1), the increasing wildfire emissions and decreasing new particle formation due to reductions in anthropogenic $\mathrm{SO}_{2}$ largely offset the effect of increased BVOC emissions on CCN concentration. In wildfire plumes, the simulated $\mathrm{CCN}$ concentrations were high even without BVOC-induced growth of smaller particles. By the year 2100, the BVOC effect on CCN was shifted northwards where background CN concentrations were increasing (Fig. 4). Overall, when estimated following Spracklen et al. (2008b) (see Sect. 2), over the Siberian domain, higher emissions due to e.g., climate change, or different $E^{*}$, led to a cloud albedo forcing ranging up to $-0.04 \mathrm{~W} \mathrm{~m}^{-2}$. While this estimate is somewhat

\section{ACPD}

$14,19149-19179,2014$

Future

biogeochemical

forcing in Eastern

Siberia

A. Arneth et al.

Title Page

Abstract

Introduction

Conclusions

References

Tables

Figures

14

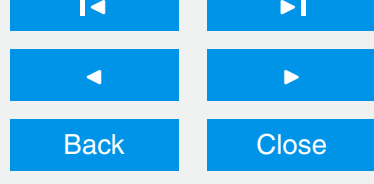

Full Screen / Esc

Printer-friendly Version

Interactive Discussion 
smaller compared to the estimate in the overall $\mathrm{CO}_{2}-\mathrm{C}$ budget, the large uncertainties that arise from the modelled processes (both in case of vegetation dynamics, and carbon cycle, and in case of secondary aerosols and wildfire) make it unlikely that the difference would be statistically significant.

5 Our analysis is the first that seeks to quantify a number of climatically relevant ecosystem processes in the large Eastern Siberian region in a consistent observational and modelling framework that accounts for the multiple interactions between emissions, vegetation and soils. These suggest that, regionally, the potential climate feedbacks from $\mathrm{CO}_{2}$ and SOA are of approximately equal magnitude. Clearly, these numbers are 10 uncertain but they pinpoint the necessity for assessing surface-atmosphere exchange processes comprehensively in climate feedback analyses. It thus remains to be investigated whether a similar picture would emerge when additional cooling or warming mechanisms are taken into consideration, e.g. SOA formation from isoprene (Henze and Seinfeld, 2006) or the albedo effect of northwards migrating vegetation (Betts, 15 2000).

Acknowledgements. A. A. acknowledges support from Swedish Research Council VR and the Helmholtz Association ATMO Programme, and the HGF Initiative and Networking Fund. The study was also supported by the Finnish Academy, grant 132100. The EU FP7 Bacchus project (grant agreement 603445) is acknowledged for financial support. P. M. acknowledges support from the VR Linnaeus Centre of Excellence LUCCI.

The service charges for this open access publication have been covered by a Research Centre of the Helmholtz Association.

Arneth, A., Miller, P. A., Scholze, M., Hickler, T., Schurgers, G., Smith, B., and Prentice, I. C.: $\mathrm{CO}_{2}$ inhibition of global terrestrial isoprene emissions: potential implications for atmospheric chemistry, Geophys. Res. Lett., 34, L18813, doi:10.1029/2007GL030615, 2007a.

\section{ACPD}

$14,19149-19179,2014$

Future

biogeochemical

forcing in Eastern

Siberia

A. Arneth et al.

Title Page

Abstract

Introduction

Conclusions

References

Tables

Figures

14

$\rightarrow 1$

Back

$>$

Close

Full Screen / Esc

Printer-friendly Version

Interactive Discussion 
Arneth, A., Niinemets, Ü., Pressley, S., Bäck, J., Hari, P., Karl, T., Noe, S., Prentice, I. C., Serça, D., Hickler, T., Wolf, A., and Smith, B.: Process-based estimates of terrestrial ecosystem isoprene emissions: incorporating the effects of a direct $\mathrm{CO}_{2}$-isoprene interaction, Atmos. Chem. Phys., 7, 31-53, doi:10.5194/acp-7-31-2007, 2007.

5 Arneth, A., Schurgers, G., Hickler, T., and Miller, P. A.: Effects of species composition, land surface cover, $\mathrm{CO}_{2}$ concentration and climate on isoprene emissions from European forests, Plant Biol., 10, 150-162, doi:10.1055/s-2007-965247, 2008.

Arneth, A., Harrison, S. P., Zaehle, S., Tsigaridis, K., Menon, S., Bartlein, P. J., Feichter, J., Korhola, A., Kulmala, M., O'Donnell, D., Schurgers, G., Sorvari, S., and Vesala, T.: Terrestrial biogeochemical feedbacks in the climate system, Nat. Geosci., 3, 525-532, doi:10.1038/ngeo1905, 2010.

Arneth, A., Schurgers, G., Lathiere, J., Duhl, T., Beerling, D. J., Hewitt, C. N., Martin, M., and Guenther, A.: Global terrestrial isoprene emission models: sensitivity to variability in climate and vegetation, Atmos. Chem. Phys., 11, 8037-8052, doi:10.5194/acp-11-8037-2011, 2011.

Betts, R. A.: Offset of the potential carbon sink from boreal forestation by decreases in surface albedo, Nature, 408, 187-190, 2000.

Dentener, F., Kinne, S., Bond, T., Boucher, O., Cofala, J., Generoso, S., Ginoux, P., Gong, S., Hoelzemann, J. J., Ito, A., Marelli, L., Penner, J. E., Putaud, J.-P., Textor, C., Schulz, M., van der Werf, G. R., and Wilson, J.: Emissions of primary aerosol and precursor gases in the years 2000 and 1750 prescribed data-sets for AeroCom, Atmos. Chem. Phys., 6, 43214344, doi:10.5194/acp-6-4321-2006, 2006.

Dolman, A. J., Maximov, T. C., Moors, E. J., Maximov, A. P., Elbers, J. A., Kononov, A. V., Waterloo, M. J., and van der Molen, M. K.: Net ecosystem exchange of carbon dioxide and water of far eastern Siberian Larch (Larix cajanderii) on permafrost, Biogeosciences, 1, 133146, doi:10.5194/bg-1-133-2004, 2004.

Ehn, M., Thornton, J. A., Kleist, E., Sipila, M., Junninen, H., Pullinen, I., Springer, M., Rubach, F., Tillmann, R., Lee, B., Lopez-Hilfiker, F., Andres, S., Acir, I. H., Rissanen, M., Jokinen, T., Schobesberger, S., Kangasluoma, J., Kontkanen, J., Nieminen, T., Kurten, T., Nielsen, L. B., Jorgensen, S., Kjaergaard, H. G., Canagaratna, M., Dal Maso, M., Berndt, T., Petaja, T., Wahner, A., Kerminen, V. M., Kulmala, M., Worsnop, D. R., Wildt, J., and Mentel, T. F.: A large source of low-volatility secondary organic aerosol, Nature, 506, 476479, doi:10.1038/nature13032, 2014.

\section{ACPD}

$14,19149-19179,2014$

\section{Future \\ biogeochemical \\ forcing in Eastern \\ Siberia}

A. Arneth et al.

Title Page

Abstract

Introduction

Conclusions

References

Tables

Figures

14

$\Delta$

4

Back

$>$

Close

Full Screen / Esc

Printer-friendly Version

Interactive Discussion 
Elmendorf, S. C., Henry, G. H. R., Hollister, R. D., Bjork, R. G., Boulanger-Lapointe, N., Cooper, E. J., Cornelissen, J. H. C., Day, T. A., Dorrepaal, E., Elumeeva, T. G., Gill, M., Gould, W. A., Harte, J., Hik, D. S., Hofgaard, A., Johnson, D. R., Johnstone, J. F., Jonsdottir, I. S., Jorgenson, J. C., Klanderud, K., Klein, J. A., Koh, S., Kudo, G., Lara, M., Levesque, E., Magnusson, B., May, J. L., Mercado-Diaz, J. A., Michelsen, A., Molau, U., Myers-Smith, I. H., Oberbauer, S. F., Onipchenko, V. G., Rixen, C., Schmidt, N. M., Shaver, G. R., Spasojevic, M. J., Porhallsdottir, P. E., Tolvanen, A., Troxler, T., Tweedie, C. E., Villareal, S., Wahren, C. H., Walker, X., Webber, P. J., Welker, J. M., and Wipf, S.: Plotscale evidence of tundra vegetation change and links to recent summer warming, Nat. Clim.

$10 \quad$ Chang., 2, 453-457, doi:10.1038/nclimate1465, 2012.

Guenther, A., Hewitt, C. N., Erickson, D., Fall, R., Geron, C., Graedel, T., Harley, P., Klinger, L., Lerdau, M., McKay, W. A., Pierce, T., Scholes, B., Steinbrecher, R., Tallamraju, R., Taylor, J., and Zimmermann, P.: A global model of natural volatile organic compound emissions, J. Geophys. Res., 100, 8873-8892, 1995.

Haapanala, S., Ekberg, A., Hakola, H., Tarvainen, V., Rinne, J., Hellén, H., and Arneth, A.: Mountain birch - potentially large source of sesquiterpenes into high latitude atmosphere, Biogeosciences, 6, 2709-2718, doi:10.5194/bg-6-2709-2009, 2009.

Hakola, H., Tarvainen, V., Bäck, J., Ranta, H., Bonn, B., Rinne, J., and Kulmala, M.: Seasonal variation of mono- and sesquiterpene emission rates of Scots pine, Biogeosciences, 3, 93101, doi:10.5194/bg-3-93-2006, 2006.

Henze, D. and Seinfeld, J. H.: Global secondary organic aerosol from isoprene oxidation, Geophys. Res. Lett., 33, L09812, doi:10.1029/2006GL025976, 2006.

Hickler, T., Vohland, K., Feehan, J., Miller, P. A., Smith, B., Costa, L., Giesecke, T., Fronzek, S., Carter, T. R., Cramer, W., Kuhn, I., and Sykes, M. T.: Projecting the future distribution of European potential natural vegetation zones with a generalized, tree species-based dynamic vegetation model, Global Ecol. Biogeogr., 21, 50-63, doi:10.1111/j.1466-8238.2010.00613.x, 2012.

Hussein, T., Dal Maso, M., Petäjä, T., Koponen, I. K., Paatero, P., Aalto, P. P., Hämeri, K., and Kulmala, M.: Evaluation of an automatic algorithm for fitting the particle number size distributions, Boreal Environ. Res., 10, 337-355, 2005.

IPCC: Climate Change 2007: The Physical Science Basis, Summary for Policymakers, Contribution of Working Group I to the Fourth Assessment Report of the Intergovernmental Panel on Climate Change, Cambridge University Press, Cambridge, 2007.
ACPD

14, 19149-19179, 2014

Future

biogeochemical

forcing in Eastern

Siberia

A. Arneth et al.

Title Page

Abstract

Introduction

Conclusions

References

Tables

Figures

14

Back

$>$

Close

Full Screen / Esc

Printer-friendly Version

Interactive Discussion 
Kajos, M. K., Hakola, H., Holst, T., Nieminen, T., Tarvainen, V., Maximov, T., Petäjä, T., Arneth, A., and Rinne, J.: Terpenoid emissions from fully grown east Siberian Larix cajanderi trees, Biogeosciences, 10, 4705-4719, doi:10.5194/bg-10-4705-2013, 2013.

Kharuk, V., Ranson, K., and Dvinskaya, M.: Evidence of evergreen conifer invasion into larch dominated forests during recent decades in Central Siberia, Eurasian Journal of Forest Research, 10, 163-171, 2007.

Khvorostyanov, D. V., Ciais, P., Krinner, G., and Zimov, S. A.: Vulnerability of east Siberia's frozen carbon stores to future warming, Geophys. Res. Lett., 35, L10703, doi:10.1029/2008GL033639, 2008.

10 Kobak, K. I., Turchinovich, I. Y., Kondrasheva, N. Y., Schulze, E. D., Schulze, W., Koch, H., and Vygodskaya, N. N.: Vulnerability and adaptation of the larch forest in eastern Siberia to climate change, Water Air Soil Poll., 92, 119-127, 1996.

Koven, C. D., Ringeval, B., Friedlingstein, P., Ciais, P., Cadule, P., Khvorostyanov, D., Krinner, G., and Tarnocai, C.: Permafrost carbon-climate feedbacks accelerate global warming, P. Natl. Acad. Sci. USA, 108, 14769-14774, doi:10.1073/pnas.1103910108, 2011.

Kulmala, M., Dal Maso, M., Makela, J. M., Pirjola, L., Vakeva, M., Aalto, P., Miikkulainen, P., Hameri, K., and O'Dowd, C. D.: On the formation, growth and composition of nucleation mode particles, Tellus B, 53, 479-490, doi:10.1034/j.1600-0889.2001.530411.x, 2001.

Kulmala, M., Petäjä, T., Mönkkönen, P., Koponen, I. K., Dal Maso, M., Aalto, P. P., Lehtinen, K. E. J., and Kerminen, V.-M.: On the growth of nucleation mode particles: source rates of condensable vapor in polluted and clean environments, Atmos. Chem. Phys., 5, 409-416, doi:10.5194/acp-5-409-2005, 2005.

Makkonen, R., Asmi, A., Kerminen, V.-M., Boy, M., Arneth, A., Guenther, A., and Kulmala, M.: BVOC-aerosol-climate interactions in the global aerosol-climate model ECHAM5.5-HAM2, Atmos. Chem. Phys., 12, 10077-10096, doi:10.5194/acp-12-10077-2012, 2012a.

Makkonen, R., Asmi, A., Kerminen, V.-M., Boy, M., Arneth, A., Hari, P., and Kulmala, M.: Air pollution control and decreasing new particle formation lead to strong climate warming, Atmos. Chem. Phys., 12, 1515-1524, doi:10.5194/acp-12-1515-2012, 2012b.

Miller, P. A. and Smith, B.: Modelling tundra vegetation response to recent arctic warming, Ambio, 41, 281-291, doi:10.1007/s13280-012-0306-1, 2012.

Moser, L., Fonti, P., Büntgen, U., Esper, J., Luterbacher, J., Franzen, J., and Frank, D.: Timing and duration of European larch growing season along altitudinal gradients in the Swiss Alps, Tree Physiol., 30, 225-233, doi:10.1093/treephys/tpp108, 2012.

\section{ACPD}

14, 19149-19179, 2014

\section{Future \\ biogeochemical \\ forcing in Eastern \\ Siberia \\ A. Arneth et al.}

Title Page

Abstract

Introduction

Conclusions

References

Tables

Figures

14

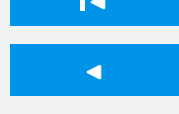

Back

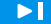

$\triangleright$

Close

Printer-friendly Version

Interactive Discussion 
Nieminen, T., Lehtinen, K. E. J., and Kulmala, M.: Sub-10 nm particle growth by vapor condensation - effects of vapor molecule size and particle thermal speed, Atmos. Chem. Phys., 10, 9773-9779, doi:10.5194/acp-10-9773-2010, 2010.

Niinemets, U., Tenhunen, J. D., Harley, P. C., and Steinbrecher, R.: A model of isoprene emis5 sion based on energetic requirements for isoprene synthesis and leaf photosynthetic properties for Liquidambar and Quercus, Plant Cell Environ., 22, 1319-1335, 1999.

Niinemets, Ü., Monson, R. K., Arneth, A., Ciccioli, P., Kesselmeier, J., Kuhn, U., Noe, S. M., Peñuelas, J., and Staudt, M.: The leaf-level emission factor of volatile isoprenoids: caveats, model algorithms, response shapes and scaling, Biogeosciences, 7, 1809-1832, doi:10.5194/bg-7-1809-2010, 2010.

O'Donnell, D., Tsigaridis, K., and Feichter, J.: Estimating the direct and indirect effects of secondary organic aerosols using ECHAM5-HAM, Atmos. Chem. Phys., 11, 8635-8659, doi:10.5194/acp-11-8635-2011, 2011.

Ohta, T., Hiyama, T., Tanaka, H., Kuwada, T., Maximov, T. C., Ohata, T., and Fukushima, Y.: Seasonal variation in the energy and water exchanges above and below a larch forest in eastern Siberia, Hydrol. Process., 15, 1459-1476, 2001.

Paasonen, P., Asmi, A., Petaja, T., Kajos, M. K., Aijala, M., Junninen, H., Holst, T., Abbatt, J. P. D., Arneth, A., Birmili, W., van der Gon, H. D., Hamed, A., Hoffer, A., Laakso, L., Laaksonen, A., Richard Leaitch, W., Plass-Dulmer, C., Pryor, S. C., Raisanen, P., Swietlicki, E., Wiedensohler, A., Worsnop, D. R., Kerminen, V.-M., and Kulmala, M.: Warminginduced increase in aerosol number concentration likely to moderate climate change, Nat. Geosci., 6, 438-442, doi:10.1038/ngeo1800, 2013.

Piao, S., Friedlingstein, P., Ciais, P., Zhou, L., and Chen, A.: Effect of climate and $\mathrm{CO}_{2}$ changes on the greening of the Northern Hemisphere over the past two decades, Geophys. Res. Lett., 33, L23402, doi:10.1029/2006gl028205, 2006.

Riahi, K., Gruebler, A., and Nakicenovic, N.: Scenarios of long-term socio-economic and environmental development under climate stabilization, Technol. Forecast. Soc., 74, 887-935, 2007.

Ruuskanen, T. M., Kajos, M. K., Hellén, H., Hakola, H., Tarvainen, V., and Rinne, J.: Volatile organic compound emissions from Siberian larch, Atmos. Environ., 41, 5807-5812, doi:10.1016/j.atmosenv.2007.05.036, 2007.
ACPD

14, 19149-19179, 2014

Future

biogeochemical

forcing in Eastern

Siberia

A. Arneth et al.

Title Page

Abstract

Introduction

Conclusions

References

Tables

Figures

14

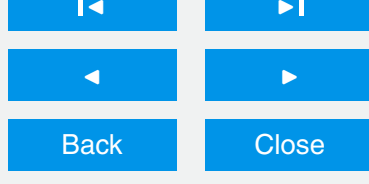

Full Screen / Esc

Printer-friendly Version

Interactive Discussion 
Schneider von Deimling, T., Meinshausen, M., Levermann, A., Huber, V., Frieler, K., Lawrence, D. M., and Brovkin, V.: Estimating the near-surface permafrost-carbon feedback on global warming, Biogeosciences, 9, 649-665, doi:10.5194/bg-9-649-2012, 2012.

Schurgers, G., Arneth, A., Holzinger, R., and Goldstein, A. H.: Process-based modelling of biogenic monoterpene emissions combining production and release from storage, Atmos. Chem. Phys., 9, 3409-3423, doi:10.5194/acp-9-3409-2009, 2009a.

Schurgers, G., Hickler, T., Miller, P. A., and Arneth, A.: European emissions of isoprene and monoterpenes from the Last Glacial Maximum to present, Biogeosciences, 6, 2779-2797, doi:10.5194/bg-6-2779-2009, 2009b.

10 Schuur, E. A. G., Vogel, J. G., Crummer, K. G., Lee, H., Sickman, J. O., and Osterkamp, T. E.: The effect of permafrost thaw on old carbon release and net carbon exchange from tundra, Nature, 459, 556-559, doi:10.1038/nature08031, 2009.

Serreze, M. C., Walsh, J. E., Chapin, F. S., Osterkamp, T., Dyurgerov, M., Romanovsky, V., Oechel, W. C., Morison, J., Zhang, T., and Barry, R. G.: Observational evidence of recent change in the northern high-latitude environment, Climatc Change, 46, 159-207, 2000.

Sistla, S. A., Moore, J. C., Simpson, R. T., Gough, L., Shaver, G. R., and Schimel, J. P.: Longterm warming restructures Arctic tundra without changing net soil carbon storage, Nature, 497, 615-618, doi:10.1038/nature12129, 2013.

Sitch, S., Smith, B., Prentice, I. C., Arneth, A., Bondeau, A., Cramer, W., Kaplan, J. O., Levis, S., Lucht, W., Sykes, M. T., Thonicke, K., and Venevsky, S.: Evaluation of ecosystem dynamics, plant geography and terrestrial carbon cycling in the LPJ dynamic global vegetation model, Glob. Change Biol., 9, 161-185, 2003.

Sitch, S., Cox, P. M., Collins, W. J., and Huntingford, C.: Indirect radiative forcing of climate change through ozone effects on the land-carbon sink, Nature, 448, 791-794, doi:10.1038/nature06059, 2007.

Smith, B., Prentice, I. C., and Sykes, M. T.: Representation of vegetation dynamics in the modelling of terrestrial ecosystems: comparing two contrasting approaches within European climate space, Global Ecol. Biogeogr., 10, 621-637, 2001.

Soja, A. J., Tchebakova, N. M., French, N. H. F., Flannigan, M. D., Shugart, H. H., Stocks, B. J., 30 Sukhinin, A. I., Parfenova, E. I., Chapin III, F. S., and Stackhouse, J. P. W.: Climate-induced boreal forest change: predictions versus current observations, Global Planet. Change, 56, 274-296, doi:10.1016/j.gloplacha.2006.07.028, 2007.

\section{ACPD}

14, 19149-19179, 2014

Future

biogeochemical

forcing in Eastern

Siberia

A. Arneth et al.

Title Page

Abstract

Introduction

Conclusions

References

Tables

Figures

14

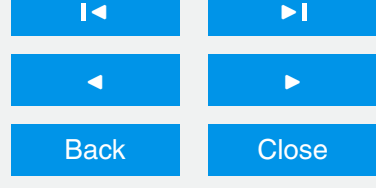

Full Screen / Esc

Printer-friendly Version

Interactive Discussion 
Spracklen, D. V., Bonn, B., and Carslaw, K.: Boreal forests, aerosols and the impacts on clouds and climate, Philos. T. R. Soc. A, 366, 4613-4626, doi:10.1098/rsta.2008.0201, 2008a.

Spracklen, D. V., Carslaw, K. S., Kulmala, M., Kerminen, V.-M., Sihto, S.-L., Riipinen, I., Merikanto, J., Mann, G. W., Chipperfield, M. P., Wiedensohler, A., Birmili, W., and Li-

5 trations, Geophys. Res. Lett., 35, L06808, doi:10.1029/2007GL033038, 2008b.

Svenningsson, B., Arneth, A., Hayward, S., Holst, T., Massling, A., Swietlicki, E., Hirsikko, A., Junninen, H., Riipinen, I., Vana, M., dal Maso, M., Hussein, T., and Kulmala, A. E.: Aerosol particle formation events and analysis of high growth rates observed above a subarctic wetland-forest mosaic, Tellus B, 58, 353-364, doi:10.1111/j.1600-0889.2008.00351.x, 2008.

Takeshi, O., Maximov, T. C., Dolman, A. J., Nakai, T., van der Molen, M. K., Kononov, A. V., Maximov, A. P., Hiyama, T., lijima, Y., Moors, E. J., Tanaka, H., Toba, T., and Yabuki, H.: Interannual variation of water balance and summer evapotranspiration in an eastern Siberian larch forest over a 7-year period (1998-2006), Agr. Forest Meteorol., 48, 1940-1953, 2008.

Tarnocai, C., Canadell, J. G., Schuur, E. A. G., Kuhry, P., Mazhitova, G., and Zimov, S.: Soil organic carbon pools in the northern circumpolar permafrost region, Global Biogeochem. Cy., 23, Gb2023, doi:10.1029/2008gb003327, 2009.

Tchebakova, N. M., Rehfeldt, G. E., and Parfenova, E. I.: Impacts of climate change on the distribution of Larix spp. and Pinus sylvestris and their climatypes in Siberia, Mitigation and Adaptation Strategies for Global Change, 11, 861-882, doi:10.1007/s11027-005-9019$0,2006$.

Thonicke, K., Venevsky, S., Sitch, S., and Cramer, W.: The role of fire disturbance for global vegetation dynamics. Coupling fire into a Dynamic Global Vegetation Model, Global Ecol. Biogeogr., 10, 661-678, 2001.

Tunved, P., Hansson, H. C., Kerminen, V. M., Strom, J., Maso, M. D., Lihavainen, H., Viisanen, Y., Aalto, P. P., Komppula, M., and Kulmala, M.: High natural aerosol loading over boreal forests, Science, 312, 261-263, doi:10.1126/science.1123052, 2006.

Vignati, E., Wilson, J., and Stier, P.: M7: an efficient size-resolved aerosol microphysics 30 module for large-scale aerosol transport models, J. Geophys. Res., 109, D22202, doi:10.1029/2003JD004485, 2004.
ACPD

$14,19149-19179,2014$

Future

biogeochemical

forcing in Eastern

Siberia

A. Arneth et al.

Title Page

Abstract

Introduction

Conclusions

References

Tables

Figures

14

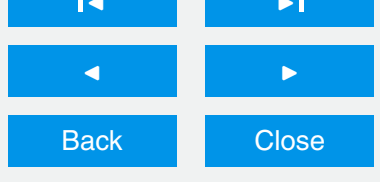

Full Screen / Esc

Printer-friendly Version

Interactive Discussion 
Wagner, V.: Analysis of a Russian Landscape Map and Landscape Classification for Use in Computer-Aided Forestry Research, International Institute for Applied Systems Analysis, Laxenburg, 1997.

Wania, R., Ross, I., and Prentice, I. C.: Integrating peatlands and permafrost into a dynamic 5 global vegetation model: I. Evaluation and sensitivity of physical land surface processes, Global Biogeochem. Cy., 23, GB3014, doi:10.1029/2008GB003412, 2009.

Zhang, K., O’Donnell, D., Kazil, J., Stier, P., Kinne, S., Lohmann, U., Ferrachat, S., Croft, B., Quaas, J., Wan, H., Rast, S., and Feichter, J.: The global aerosol-climate model ECHAMHAM, version 2: sensitivity to improvements in process representations, Atmos. Chem. Phys., 12, 8911-8949, doi:10.5194/acp-12-8911-2012, 2012.

\section{ACPD}

\section{4, 19149-19179, 2014}

\section{Future \\ biogeochemical \\ forcing in Eastern \\ Siberia}

\section{A. Arneth et al.}

\section{Title Page}

Abstract

Introduction

Conclusions

References

Tables

Figures

14

4

Back

Close

Printer-friendly Version

Interactive Discussion 
Table 1. Simulated changes in net primary productivity, BVOC emissions, and C pool size in vegetation and soils. Unless stated otherwise, values are for the simulated Siberian domain $\left(76-164^{\circ} \mathrm{E}, 46-71^{\circ} \mathrm{N}\right.$ ), and represent an area of $1.2 \times 10^{7} \mathrm{~km}^{2} . \mathrm{NPP}_{\text {global }}$ (given as a reference value) is global vegetation net primary productivity. $\mathrm{BVOC}$ in $\mathrm{Tg} \mathrm{Ca}^{-1}, \mathrm{CO}_{2}-\mathrm{C}$ fluxes in $\mathrm{Pg} \mathrm{Ca}^{-1}$, $\mathrm{C}$ pools in Pg C. Simulations for monoterpene emissions for the boreal needleleaf summergreen (BNS) plant functional type were made using maximum $\left(9.6 \mathrm{\mu g} \mathrm{g} \mathrm{g}^{-1} \mathrm{~h}^{-1}\right)$ and minimum $\left(1.9 \mu \mathrm{g} \mathrm{g} \mathrm{g}^{-1} \mathrm{~h}^{-1}\right)$ values for $E^{*}$ measured in Spasskaya Pad (see text), $E^{*}=6.2 \mu \mathrm{g} \mathrm{g}^{-1} \mathrm{~h}^{-1}$ represents a weighted average from all observations at the Spasskaya Pad location. For BVOC, $\mathrm{CO}_{2}$ inhibition was switched on and off (Arneth et al., 2007b).

\begin{tabular}{|c|c|c|c|}
\hline & $1981-2000$ & $2031-2050$ & $2081-2100$ \\
\hline $\begin{array}{l}\text { NPP }_{\text {global }} \\
\text { NPP }\end{array}$ & $\begin{array}{c}58 \pm 15 \\
3.5 \pm 0.2\end{array}$ & $\begin{array}{c}66 \pm 17 \\
4.5 \pm 0.2\end{array}$ & $\begin{array}{c}76 \pm 14 \\
5.9 \pm 0.2\end{array}$ \\
\hline \multicolumn{4}{|c|}{ Carbon in circumpolar permafrost region } \\
\hline $\begin{array}{l}\text { Vegetation } \\
\text { Litter } \\
\text { Soil ( } 0 \text { to } 2 \mathrm{~m} \text { depth) } \\
\text { Total }\end{array}$ & $\begin{array}{c}109 \pm 0.7 \\
81 \pm 0.5 \\
454 \pm 0.03 \\
644 \pm 0.4\end{array}$ & $\begin{array}{c}106 \pm 1.6 \\
68 \pm 0.3 \\
392 \pm 0.4 \\
567 \pm 1.1\end{array}$ & $\begin{array}{c}78 \pm 1.8 \\
44 \pm 0.3 \\
255 \pm 0.5 \\
377 \pm 1.0\end{array}$ \\
\hline \multicolumn{4}{|c|}{ C-pools in permafrost area of study domain } \\
\hline $\begin{array}{l}\text { Vegetation } \\
\text { Litter } \\
\text { Soil ( } 0 \text { to } 2 \mathrm{~m} \text { depth) } \\
\text { Total }\end{array}$ & $\begin{array}{c}41 \pm 0.6 \\
40 \pm 0.3 \\
216 \pm 0.06 \\
297 \pm 0.4\end{array}$ & $\begin{array}{c}38 \pm 0.6 \\
34 \pm 0.2 \\
187 \pm 0.1 \\
259 \pm 0.4\end{array}$ & $\begin{array}{c}35 \pm 0.7 \\
23 \pm 0.2 \\
140 \pm 0.3 \\
198 \pm 0.2\end{array}$ \\
\hline \multicolumn{4}{|c|}{ C-pools in entire Siberian study domain } \\
\hline $\begin{array}{l}\text { Vegetation } \\
\text { Litter } \\
\text { Soil ( } 0 \text { to } 2 \mathrm{~m} \text { depth) } \\
\text { Total }\end{array}$ & $\begin{array}{c}45 \pm 0.5 \\
41 \pm 0.5 \\
219 \pm 0.3 \\
305 \pm 1.1\end{array}$ & $\begin{array}{c}56 \pm 1.5 \\
43 \pm 0.3 \\
221 \pm 0.3 \\
320 \pm 2.1\end{array}$ & $\begin{array}{c}77 \pm 2.8 \\
41 \pm 0.7 \\
223 \pm 0.3 \\
342 \pm 2.0\end{array}$ \\
\hline
\end{tabular}

\section{Future \\ biogeochemical \\ forcing in Eastern \\ Siberia}

A. Arneth et al.

\section{Title Page}

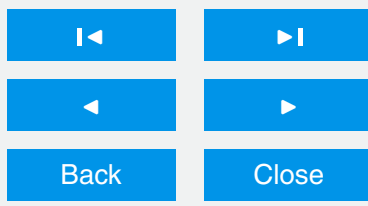

Full Screen / Esc

Printer-friendly Version

Interactive Discussion 
Table 1. Continued.

\begin{tabular}{|c|c|c|c|}
\hline & $1981-2000$ & $2031-2050$ & $2081-2100$ \\
\hline \multicolumn{4}{|c|}{ BVOC, with $\mathrm{CO}_{2}$ inhibition } \\
\hline Total_iso & $4.11 \pm 0.29$ & $4.52 \pm 0.32$ & $4.80 \pm 0.24$ \\
\hline & & & \\
\hline & & & \\
\hline & & & \\
\hline & & & \\
\hline & & & \\
\hline Total & & & \\
\hline Total_1 & $1.60 \pm$ & $1.6 \varepsilon$ & \\
\hline Total_^ & 1.75 & & \\
\hline \multicolumn{4}{|c|}{ BVOC, no $\mathrm{CO}_{2}$ inhibition } \\
\hline & & & \\
\hline & & & \\
\hline BINE, N & $0.22 \pm 0$ & $0.30=$ & $0.42 \pm 0.02$ \\
\hline BNS, MT_1.9 & $0.08 \pm 0$ & $0.14 \pm 0.02$ & $0.20 \pm 0.03$ \\
\hline BNS, MT_6.2 & & & $0.52 \pm 0.07$ \\
\hline & & & \\
\hline & $1.34 \pm 0.09$ & $1.92 \pm 0.13$ & \\
\hline Total_MT & $1.47 \pm 0.10$ & $2.13 \pm 0.16$ & $3.36 \pm 0.27$ \\
\hline Total_MT BNS_9.6 & $1.67 \pm 0.13$ & $2.47 \pm 0.22$ & $4.90 \pm 0.47$ \\
\hline
\end{tabular}

\section{Future \\ biogeochemical \\ forcing in Eastern \\ Siberia \\ A. Arneth et al.}

\section{Title Page}

\section{Abbreviations:}

NPP: net primary productivity

BNE: boreal needleleaf evergreen PFT, shade tolerant

BINE: boreal needleleaf evergreen PFT, intermediate shade-tolerant

BNS: boreal needleleaf summergreen PFT ("larch"), shade intolerant

continentality index as in Sitch et al. (2003)

Iso: isoprene

MT, monoterpenes

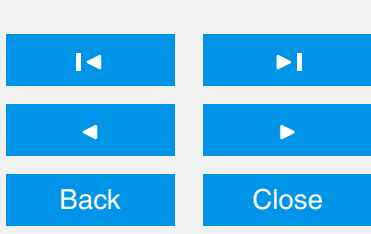

Full Screen / Esc

Printer-friendly Version

Interactive Discussion 


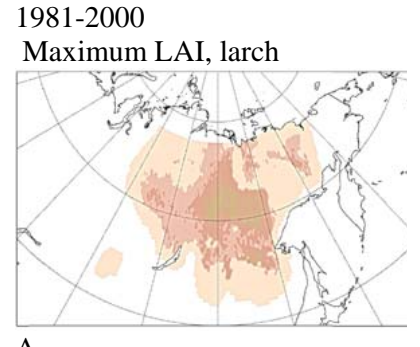

A

2081-2100

Maximum LAI, larch

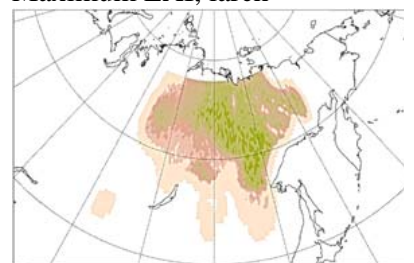

B
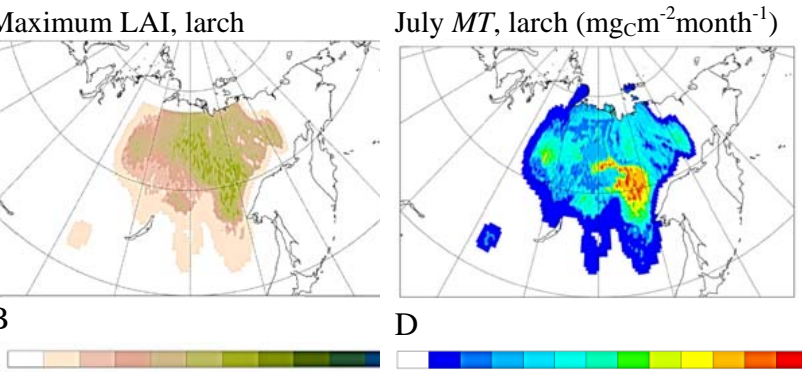

$\mathrm{D}$

$\mathrm{D}$

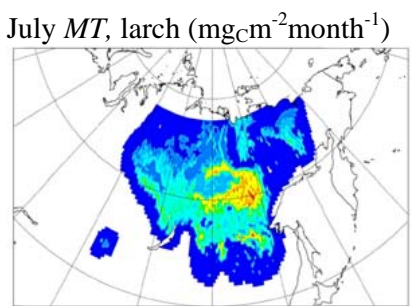

$\mathrm{C}$

July $M T$, larch $\left(\mathrm{mg}_{\mathrm{C}} \mathrm{m}^{-2} \mathrm{month}^{-1}\right)$

$\begin{array}{llllllllllll}5 & 10 & 15 & 20 & 25 & 30 & 35 & 40 & 45 & 50 & 55 & 60\end{array}$
Max. thaw depth (m)

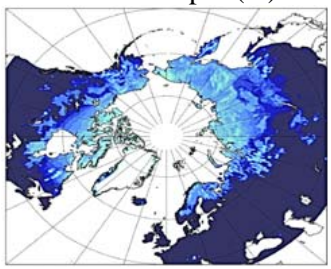

E

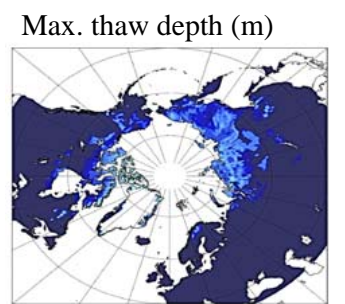

$\mathrm{F}$
Figure 1. Simulated maximum summer leaf area index (LAl; A, B) and July emissions of monoterpenes (C, $\mathbf{D} ; \mathrm{mg} \mathrm{C} \mathrm{m}^{-2} \mathrm{month}^{-1}$ ) from Eastern Siberian larch. The latter were calculated applying emission factors of 6.2, obtained from the measurements at Spasskaya Pad. (E, F) Maximum permafrost thaw depth (August), shown as circumpolar map for comparison with Tarnocai et al. (2009). Values are averages for a simulation 1981-2000 (A, C, E), and for 2081$2100(B, D, F)$, applying climate and $\mathrm{CO}_{2}$ concentrations from ECHAM-RCP8.5. Emissions in (C, D) do not account for direct $\mathrm{CO}_{2}$ inhibition.
ACPD

14, 19149-19179, 2014

\section{Future \\ biogeochemical \\ forcing in Eastern \\ Siberia}

A. Arneth et al.

\section{Title Page}

Abstract

Introduction

Conclusions

References

Tables

Figures

14

4

Back

$>$

Close

Full Screen / Esc

Printer-friendly Version

Interactive Discussion 


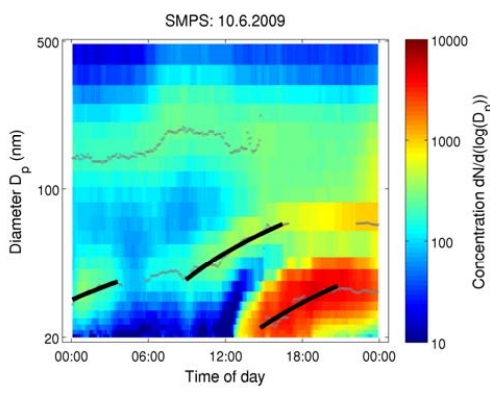

A

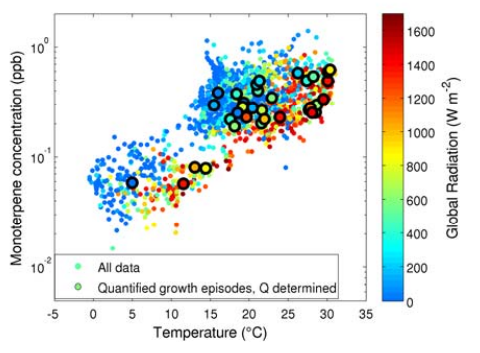

C

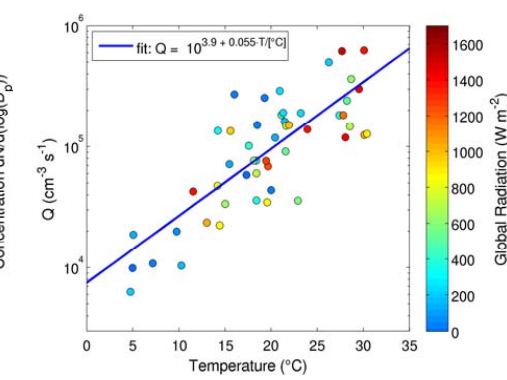

B

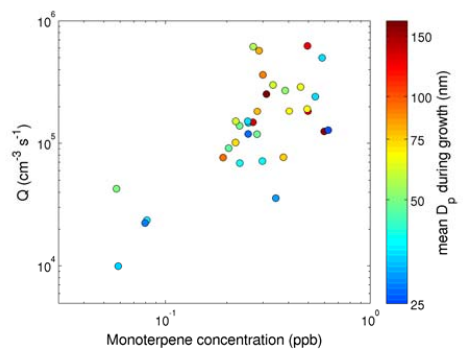

D

\section{Future \\ biogeochemical \\ forcing in Eastern \\ Siberia}

A. Arneth et al.

Title Page

Abstract

Introduction

Conclusions

References

Tables

Figures

14

DI

Back

Close particles with different diameters $\left(D_{\mathrm{p}}, \mathrm{nm}\right)$ over the course of a day, small circles are mean diameters of concentration modes fitted for each measurement, and the temporal change of these diameters is represented with black lines from which the growth rate is calculated. (B) shows the calculated volumetric source rates of condensing vapours $(Q)$ as a function of air temperature $\left({ }^{\circ} \mathrm{C}\right)$; data are separated by levels of global radiation. (C) Monoterpene concentrations (half hourly data) measured above the canopy $v s$. temperature (data separated by radiation, the data applied in (B) and (D) are indicated by encircled symbols), and relationship between volumetric source rate of condensing vapours and monoterpene concentration (D; data separated by particle diameter).

Full Screen / Esc

Printer-friendly Version

Interactive Discussion 

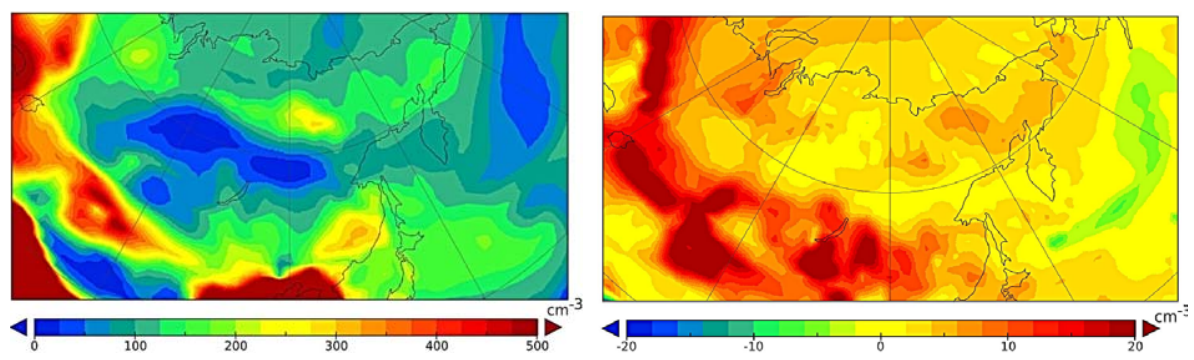

Figure 3. Annual average boundary-layer CCN $(0.2 \%)$ concentration $\left(\# \mathrm{~cm}^{-3}\right)$ in Siberia with present-day anthropogenic and BVOC (for BNS: $E^{*}=1.9$ ) emissions (left panel), and changes in $\mathrm{CCN}(0.2 \%$; right panel) concentration due to increase in BVOC emission between years 2000 and 2100 (simulations with $\mathrm{CO}_{2}$ inhibition off).

\section{ACPD}

14, 19149-19179, 2014

\section{Future \\ biogeochemical \\ forcing in Eastern \\ Siberia}

A. Arneth et al.

Title Page

Abstract

Introduction

Conclusions

References

Tables

Figures

14

4

Back

Close

Full Screen / Esc

Printer-friendly Version

Interactive Discussion 

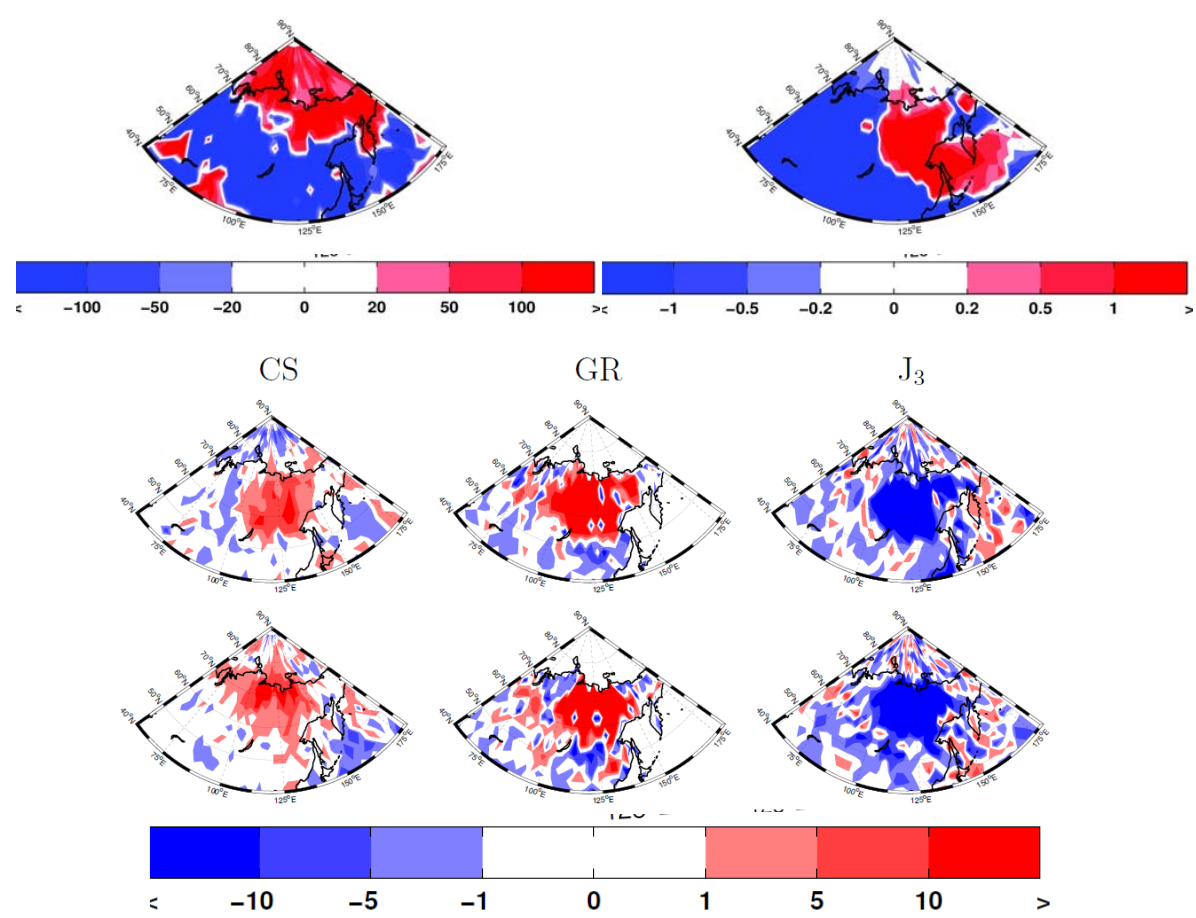

Figure 4. Top panel: absolute change in $\mathrm{CN}$ (top left) and $\mathrm{CCN}(0.2 \%)$ concentrations (top right, $\mathrm{cm}^{-3}$ ) between years 2000 and 2100 using BVOC emission estimates that included $E^{*}=6.2$ for the BNS PFT. Lower panel: relative change in condensation sink (CS), aerosol growth rate (GR) and formation rate, $J$, of $3 \mathrm{~nm}$ particles for year 2000 (top row) and 2100 (bottom row). Effects of different BVOC emissions are shown by \% differences for simulations using BVOC emissions with $E^{*}=9.6$ and $E^{*}=1.4$ for the BNS PFT.

\section{ACPD}

$14,19149-19179,2014$

\section{Future \\ biogeochemical \\ forcing in Eastern \\ Siberia}

A. Arneth et al.

Title Page

Abstract

Introduction

Conclusions

References

Tables

Figures

14

$\Delta$

4

Back

Close

\section{Full Screen / Esc}

Printer-friendly Version

Interactive Discussion 


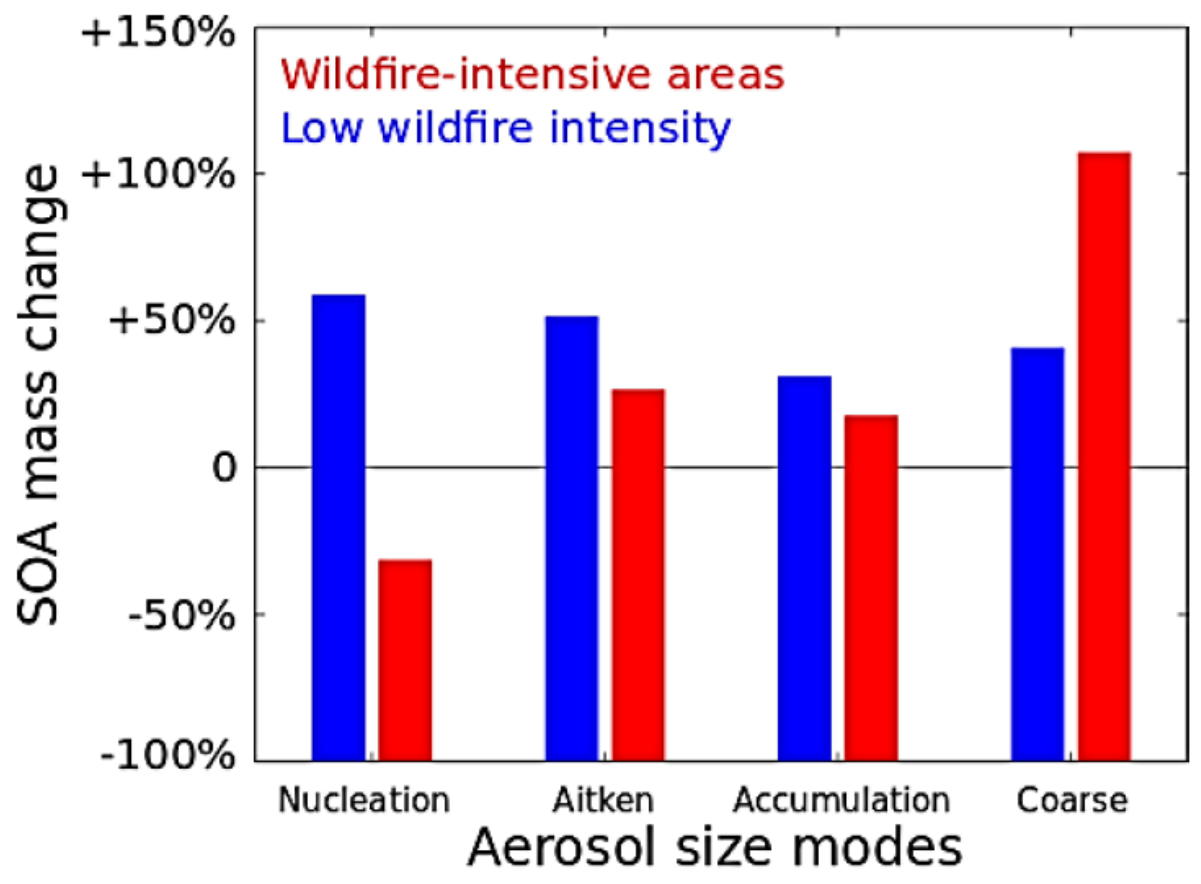

Figure 5. Relative increase in SOA mass, simulated by ECHAM5-HAM in different aerosol size modes due to BVOC emissions increase from the year 2000 to 2100 . The areas are averaged over Siberia, and the BVOC emissions for years 2000 to 2100 (example is for $E^{*}=1.9$ ).

\section{ACPD}

14, 19149-19179, 2014

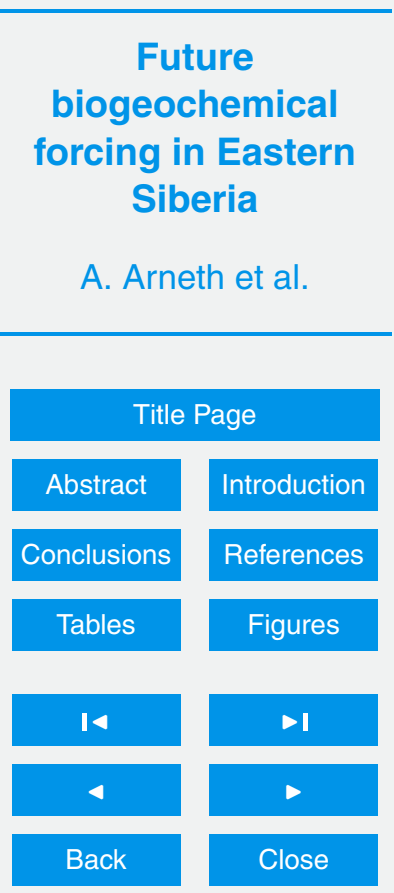

Full Screen / Esc

Printer-friendly Version

Interactive Discussion 
1981-2000, Monoterpenes

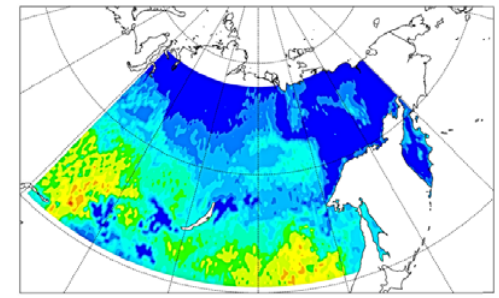

2081-2100, Monoterpenes, $\mathrm{CO}_{2}$-inh. on

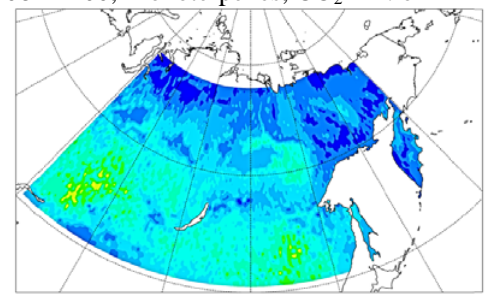

2081-2100, Monoterpenes, $\mathrm{CO}_{2}$-inh. off

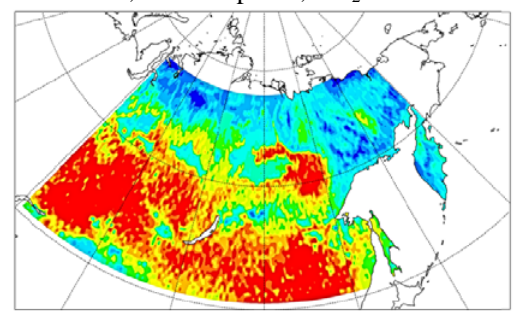

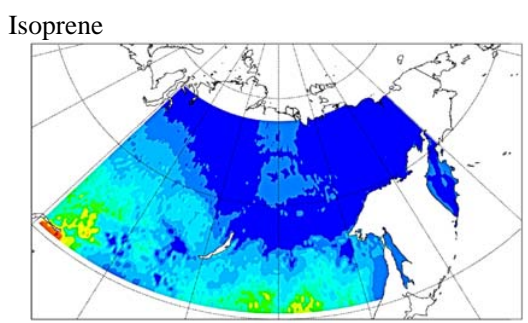

Isoprene, $\mathrm{CO}_{2}$-inh. on

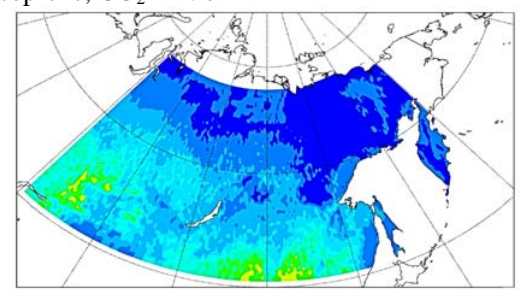

Isoprene, $\mathrm{CO}_{2}$-inh. off

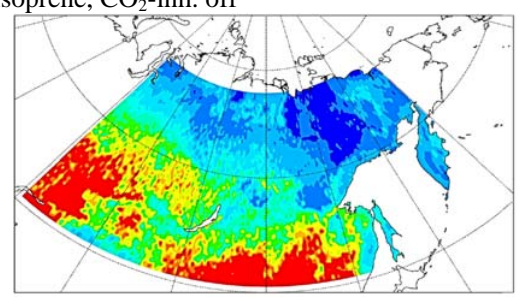

Figure A1. Present-day (top: 1981-2000) and end of 21st century (bottom: 2081-2100) total monoterpene (left) and isoprene (right) emissions for the month July $\left(\mathrm{mg} \mathrm{C} \mathrm{m}^{-2} \mathrm{month}^{-1}\right)$. Simulations show results with $\mathrm{CO}_{2}$ inhibition switched on and off.

\section{ACPD}

\section{4, 19149-19179, 2014}

\section{Future \\ biogeochemical \\ forcing in Eastern \\ Siberia}

\section{A. Arneth et al.}

Title Page

Abstract

Introduction

Conclusions

References

Tables

Figures

14

DI

4

Back

Close

Full Screen / Esc

Printer-friendly Version

Interactive Discussion 